\title{
Migrants: Signs of a New Era. Interview with Father Solalinde.
}

Diego Contreras-Medrano, University of Oregon

Diegoc@uoregon.edu

Pedro García-Caro, University of Oregon

pgcaro@uoregon.edu

Translated by Bryce Sprauer

\begin{abstract}
This interview was carried out in the context of the visit of Father Solalinde to the University of Oregon in May 2018. It deals with immigration policies in the US and Mexico, and the resistance strategies that have been developed in recent years to escape from the repression and corruption around migrants and their travel North. Important for the context is also the presidential campaign of Andrés Manuel López Obrador that would win the elections in July and whose six-year term started in December of 2018.
\end{abstract}

Keywords: migration, US-Mexico relations, Mexican presidency, state-church relations, human trafficking 
$\Delta$ lejandro Solalinde Guerra (Mexico, 1945) is a Mexican Catholic priest the social order, rebels against injustice. Solalinde came to the University of Oregon in May 2018 to offer the "Father Las Casas Annual Conference on Human Rights in the Americas" under the auspices of the UO Latin American Studies Program, the local MeCha, "Adelante Sî," the Migrant Institute of Guanajuato, Oak Hill School, and the Office of the Vice President for Equity and Inclusion, Yvette Alex Assensoh. During the six days he was in Eugene, his appearances proliferated: he was on the local public radio, invited to the program "Ahora Sî" by Armando Morales (KLCC 89.7) for a bilingual interview, he met with Latin American Studies classes, with UO MeCha students, and with representatives of MORENA in Oregon.

His manner is direct, as well as his analysis. Solalinde has been a defender of human rights with an unmistakable voice and action over the past two decades. In his writings, in his homilies, in his numerous appearances in the public media, Solalinde's message is easily understandable: dignity and humane treatment for all, transgressing the borders traced on the skin, between ethnicities, nationalities, beliefs, and classes. Founder of the shelter "Hermanos en el Camino" in July 2007 in the city of Ixtepec (Oaxaca), Solalinde has created a network of refuge, follow-up monitoring and support for migrants who cross the Mexican territory to the United States. Solalinde struggles to awaken an awareness of the humanitarian crisis and the passivity of all the states and agents involved. The design and function of his shelter resemble those of a refugee camp: a welcoming space that has hosted more than a thousand individuals at different times, and that Father Solalinde has come to defend by putting his life in danger, as revealed in this interview. His public challenges to the Catholic hierarchy in Mexico and his denunciation of local and national authorities show that Solalinde's work is effective: Solalinde has become a public spokesperson for hundreds of thousands of human beings 
who do not have access to a dignified life and that are treated as true human herds in a context of unpunished violence, absence of effective humanitarian public policies, and mass trafficking of people and narcotics, often coordinated by organized criminals and state agents beyond all control. Solalinde visualizes migration northward as a sign of the collapse of the modern state in ample parts of Central America and Mexico: migrants are actors of a change that marks the end of one era and the beginning of another. Despite the difficulties, prohibitions, violence, walls and borders, people continue occupying space, fleeing from nameless daily violence, looking for new opportunities for a better life. But first and foremost, they go on transforming fear into courage, demanding dignity and full recognition of their human right to a full and peaceful life.

In our interview, Solalinde evokes “The Impossible Dream," a song from Man of La Mancha, a musical based on Don Quijote performed on Broadway in 1965. The song celebrates a struggle to reach an unattainable star, evoking a march through hell in search of noble ideals: "To be willing to march / March into hell / For that heavenly cause [...]." The new era, which according to Solalinde, migrants and refugees inaugurate, is a noble ideal, a future of recognition of injustices and reparations, of humanity's triumph over the merchandising of bodies and things, a new era that is always around the corner.

García-Caro: Yesterday we were talking about The Migrants of the South, your book that came out in December of 2017 and about the moment when you decided to build the shelter. Also, today at lunch we have been talking about the fight with the local bishop regarding the shelter, the property of the shelter and who owns it. I would like to think about the possible expansion of the network of shelters. It seems to me a very powerful image, 
that the network of shelters becomes almost a kind of direct alternative that breaks with the wall. It is like a perpendicular line cutting through the wall, in symbolic terms it's a line that defies the regimes of control... [Solalinde asks us to stop the recording briefly].

Solalinde:

The first approach might be to discuss the meaning of migration. Emigration... if you want, has manageable aspects, doable aspects, tangible aspects, measurable, quantifiable, that you can see as a phenomenon, as social scientists do. But there is an intangible part; there is a part that does not correspond to the parameters of those who are not accustomed to seeing the facts.

I was saying earlier that an event is a relevant fact in History, and I would define the passage of migrants as one such event. The current migration is the most relevant fact. It is the most important sign of a gestation of a new era. First, when a migrant, I am talking about migrants, 247 million people in movement, in a situation of human mobility in the world - I refer to Africa, but also to America, to say the least, but they are not the only migrations - something that you should ask yourself, "why did they have to leave?," because they are not entrepreneurial migrations. They are not migrations of conquest. They are forced migrations. Then you must ask yourself why are there no longer minimum conditions of life in the places of origin? Why are people forced to emigrate? Because you cannot live anymore. So that question in itself, opens the possibilities of an 
investigation that will lead you to a systemic expiration. The capitalist system has provoked that because it no longer guarantees the lives of people. But not only is capitalism expired, modernity has just expired, the modern state, because it no longer guarantees... The modern state succumbed to the capitalist factual power and that's it. That state of modernity has already been left behind to give way to post-modernity, to an administrator state, a state that administers the interests of the capitalist oligarchy of the world.

García-Caro:

That is why I asked-I know you do not want to be a protagonist-but I asked you how the network of shelters that you have helped to create is a perpendicular response that radically questions and resists the wall...

Solalinde:

If you allow me, I could get to these circumstantial issues, but I would like to talk a little more about the general framework. Because what you ask me is certainly circumstantial, important, it must be answered, because they are a systemic response, a systemic aggression too. An attack on human rights.

I just want to tell you that the migrant announces, in a few words, that something is already broken, something is out of order, it does not work anymore. So they begin the search for a new life. That new life can be called a new age, a new era. You can call it what you want, but it is something that we do not yet know, we still do not know what will happen. But it is underway, yes. That it is 
in process, yes. Now, another issue is the treatment, the vicissitudes suffered by migrants in transit, both from Africa to Europe in the Mediterranean, and from the South to the United States through Mexico. Mexico is the equivalent - the danger, the risk - of the Mediterranean Sea. Mexico, as a transit country, is very dangerous, so many deaths have taken over the Mediterranean, just like with the passage through Mexico. Recognizing this, then, knowing this, we can already understand that we have an event, a systemic struggle between two poles: one, the capitalist system, represented by Donald Trump, that does not want migrants, which is a resistance against migrants. On the other hand, there are also migrants who have a life of their own, who do not get scared by Trump and who are not inhibited by the most racist and anti-immigrant laws that you can imagine.

We have the two blocks that are facing each other. I do not want to call it confrontation because it is not confrontation. On the side of the supremacists, it is. On the side of the capitalists, yes. On the side of the agents of the state at the service of capitalist powers, yes: it is an aggression. But on behalf of the migrants, no. It is not a war: it is a resistance. It is a very great power, to walk and move forward; where they have to advance against all risks, against all threats. As if they were in a gear that nobody can stop. That is what I see.

All right then, now we can talk. In the south I was a missionary, a priest who also realizes all these things 
about capitalist structures and all this, because of the knowledge I have, of having had the opportunity to have been in many places and to confirm it. Back in 2013, in the US, it was very useful for me to visit 26 states of the American Union in the context of an informational caravan about migrants that we organized. So between the preparation and the execution of the caravan, we visited 26 states. I was very impressed to learn a little more from inside the USA in relation, precisely, to migration. Always as a transversal axis that is touching everything. And I was in Congress and I was listening to congressmen, how they talked about migration, whether immigration reform was viable or not. I listened to Nancy Pelosi, and everything they said impressed me.

So, everything that I lived has helped me so that, in the south, which is where I had to be, a change began to take shape in response. When I arrived, I did not know what was happening. What was happening and what was going to happen later with the migrants, we did not even imagine it. Everything was hidden, it was not visible. There was a time when I had to make the decision, because I was threatened with death. And I said, "what do I do? If I shut up, I have to flee, I have to go and leave things as they are. Or stay, even risking myself, but fulfill the accompaniment that as a priest, as a missionary, I have to provide to migrants."

Six Jesuits were threatened to death with weapons. The Zetas. So they understood and left, but they told me: "You have two roads. One, that you ask for help from the 
Miguel Agustín Pro center of the Jesuits in Mexico, and that they begin to see how they are going to deal with this matter; or that you go, that you leave because they are going to kill you." A father, a colleague of mine told me: "do not talk like you are talking because they are going to kill you." They threatened me there and I had to shut up. I kept thinking, and I did not even have time to decide. It was necessary to do it. I had two roads, to call the press and start publishing all of it. And I opted to call the press, to make it known and create all the possible scandal in order to make them realize what was happening.

From that moment, they began to visualize everything that was happening: who were the ones that were threatening the migrants, what they wanted to do with them, what sort of massive-business projects they had to do with them regarding kidnapping, all this. And of course, terrible years came: from 2007 until about 2012, which was still very tough. From 2012 on, there were threats, sporadic attacks. But it was not that constant tension anymore, as [the Zetas] were losing ground. A key point was when in 2010, there was a kidnapping of fifty migrants; it was out of the norm. There were fifty migrants who had been kidnapped, I have 21 witnesses and the government of Oaxaca and the federal government tell me, "If Father Solalinde does not file a criminal complaint against those who were doing that, that is, the Zetas, we can not do anything." It's that easy, look. "If he does not file a complaint, we can not 
do anything." And I said, "I'm going, again, to be in the same situation. If I do not denounce, then I have to go now. But if I denounce, I have to stay and I will not live two days here; they will not let me live," he said, "they are going to kill me." And I had to make the decision. On December $22^{\text {nd }}$ of that year, 2010, I made the decision and I filed four lawsuits against the Zetas.

García-Caro: 2012 is when you had to leave Oaxaca...

Solalinde:

The situation got worse. Then, I filed them on $22^{\text {nd }}$. On the $23^{\text {rd }}$, I experienced a situation that I have described as "pre-death" because I do not know another way to call it. I was sure that I would die, very sure that I was going to die. That's on the $22^{\text {nd }}$. On the $22^{\text {nd }}$ I said, "I'm not going to wake up one..."

García-Caro: $\quad$...It's almost a "chronicle of a death foretold," as in the novel by García Márquez...

Solalinde:

...I felt that way, that's how I felt. And I woke up on the $23^{\text {rd }}$ and I said, "is it worth living that way with fear? No. And the migrants?" The shelter was [completely full]. The first time I remember, the first time we were going to enjoy Christmas Eve, because we had never had the opportunity to have a Christmas Eve, ever. I called everyone and said, "Look, we are really threatened. We are really threatened with death, but it is not worthwhile that we are living hiding ourselves, and living in fear. 
It's not worth it and we're going to forget everything. If they kill us they kill us, but this Christmas, we will celebrate well and we will be happy and we will play music and we will put up ornaments, and we will make a very good dinner." And that's what we did. And that Christmas happened like the first and the only one we had at that moment. After that, they let me live and I continued living. What is the cause of that? I think it was caused by the increasing visibility of the migration issue; everything they wanted to do with them, to conduct large and massive kidnappings... they knew their business was exposed. They were exposed and in serious trouble and they could no longer do it with so much media, they could not do anything, because all the reflectors were placed on them. They opted for not creating more problems and retired to Veracruz. And then from Veracruz to the north. And then in the north they decided that, why fight so much with me in the south, if there in the north they could wait for the migrants quietly and kidnap them there. So they did nothing, they waited for them to arrive alone.

García-Caro:

There is an argument here, or a logic that is relatively difficult to understand outside of Mexico; that of a paramilitary group that leaves the government, the Zetas, which is dedicated to kidnapping and mass murdering hundreds, possibly thousands, of Mexican citizens, but also Central Americans. It is difficult to understand the purpose. That is to say, that they rob is one thing, even 
that they can trade, one can speculate.... But there have been people who have investigated what the motivations of the Zetas are to carry out this violence...

Solalinde:

The Zetas were not always what they became later on. I believe that they, in spite of everything, were educated people. All Catholics, all with an elite, army education. But something happened to them. Felipe Calderón begins to make his absurd war against drug trafficking and then somehow he hits them and for a moment he decapitalizes them, and they can no longer pay out for the drugs nor keep receiving them on credit. Those things are not done, they are paid immediately. Because you do not know if in five minutes they're going to kill you or they're going to kill someone else. They did not have money, so they discovered - they saw because it was their route from Chiapas, from Tenosique; as much by Tapachula as by Tenosique - they discovered the migration flow. In December 2006, Felipe Calderón carries out an operation on the southern border. In that operation on the southern border, they do not do anything against anyone, but it provokes a containment of the migration flow. The migration flow was delayed for months. When everything was withheld because it was not going anywhere, people began to pass through in groups of eight hundred, in groups of one hundred in each train. Two thousand, because once two thousand arrived on the same train, and one thousand two hundred people arrived at the shelter, because it is the 
maximum number that have entered together, all at once. One thousand two hundred people.

García-Caro:

Solalinde:
What is the capacity of the shelter?

The shelter may have a very small capacity, but it has a lot of land. It is 16,000 square meters. At any given time, you can host people on the floor or wherever, thousands fit in there. It's like a refugee camp.

When they arrive and begin to move on, the Zetas begin to discover things; they begin to experiment. First, they extort the migrants. But it was not enough; the Zetas were not so ordinary, so to speak, to settle for extortion, if they are not assailants. They go big. Then they began to discover how... the migrants are poor. The migrants from the south do not have money, but they began to think, to see: “They don't, but where are they going? To the United States. There they have some acquaintance, or family member. Here there are no dollars, but there are dollars there." They thought that they could take the money from the relatives, and they did not know if the relatives were going to respond or not. And they started to do the tests. I was there when they started doing this, the relatives started calling me, directly to me. "Father, they are asking me for money because they say they are kidnapped." And I said, "Well, let me see," because I did not know anything, this had just started. By the time I had realized it, they discovered that the relatives could pay, and that the life of a relative, that the life of a poor 
man is worth so much to them that they were willing to pay. They did not even know how much they were going to charge, they began to prove how much they could pay, until they arrived more or less at a fee that was between one and three thousand dollars per person. And they started paying.

After that, they made techniques, techniques for convincing. People were taken to a place where there was a cell phone signal, and then they called a family member and got the rescue money. Those who are good, especially the Guatemalans, they do not fight, they do not resist. They pay because they have very important social networks, most of them are indigenous. They pay, they do not mistreat them; rarely do they kidnap them. They pay in advance and so they no longer kidnap them and they let them pass. Because the profit does not generate problems for the drug trafficking. This is what they did to them and they realized that the poor are worth something. They let the ones go who could not pay at first. But when they came back to us later, we wanted to make a deposition. We filed a report and began to quantify it all, how many were being kidnapped. And we were able to account for investigations that 10,000 migrants were kidnapped each semester. Every six months this amounted to a twenty-five million dollar profit. Every six months. And that's just for those we could account for. Obviously it was much more, but it was not possible for us to register beyond ten thousand migrants. 
They realized that, if they leave people alive, they will talk, and they do not want them to talk, so they started killing them. They began to fill wells, fill them with bodies. They began to take them to the lizards, because in the area where they were carrying out the kidnappings, there were lakes with lizards and the lizards ate them - then they began to fill caves, in Veracruz. Finally, they invented a new technique [to disappear people]: a Zeta that was called the Sheep - I think they must have already killed him - invented this technique of a 200-liter barrel. Several people were needed: first you need a hit man, a hit man who was responsible for nothing more than killing them. Then the butcher, responsible for cutting them to fit the bodies in barrels of 200 liters. And then the other was the cook or the pozolero, to cook them. They already had experience of how to do it without leaving anything but charred remains. But still, there was still another one that in recent years we have been discovering. The last person was to collect the rest of the barrels and then to go toss them, however not in the same pit, but in different pits so that it would take even more work, if there were any remains with DNA, because there would be no way to put the body parts back together. This happened for instance in Colinas de Santa Fe, in Veracruz. Solecito discovered this, when his relatives were finding the remains of a relative, but he noticed that there was only one or two body parts, but the rest was not there. At first, they thought that the other body parts had been 
burned, but later they found the rest of the same person in another pit. In other words, it was the perfect crime.

That day when we thought they were going to kill me, well we said, "let's risk it" without knowing if they were really going to kill me or not. But I was sure of one thing, I could not remain silent, nor could I stop raising a complaint, when it should be raised. But then they did not kill me. Several times, the Zetas tried to kill me... I still think there is something I do not understand: at least once, in February 2008, a Zeta called Reinosa said, that very night he was going to come and kill me with his own hands. Those were his words. "With my own hands." That same night, he entered, but not to kill me. He entered and did some kind of ritual. I used to sleep in a "tracker" truck because there was no place to sleep, and I left the window open because it was very hot, but near the chapel because that's where the migrants slept. I was taking care of them; I was on the lookout so that nothing would happen to them. And that night I fell asleep and the Reinosa entered. With a pistol in his hand, he put his hand in and pointed the gun at my head, and left, but he did nothing. A cook who had stayed the night there saw it, because at that time, he was there near the hostel, a tower with a very strong focus, it practically lit the entire courtyard of the hostel, as if we had no light. The next morning, I asked him about what had happened the night before. He said "father, a person came in," and he described everything to me as it had happened. And I said, "Are you sure? 
What did he look like?" And he described to me: he was güero, blond, light eyes, short, thin. I got a good look at him. He came in, but he did not do anything to me, but he caught my attention... Two years went by. Two years later, I was always curious as to why they had not killed me: he had the gun; he had said that he was going to kill me with his own hands; he came inside; there had not been any defense or resistance. He would have hit me with two bullets then and there, and that would have been that...

Two years later, a young man who was a smuggler before-he worked as a guide, it was his job. It was his job. Like any other person. But he did not abuse others. He did not charge them extra, he charged them half, and the other half he would receive from the room in the United States; he gave it to his family, without any complaint of having abused the women, or anything. This young man was called Juan Carlos, he was, I believe, from Salamanca. He arrived with me. I had seen him just as any other person with a job. And then I saw him as a human trafficker. But it just so happened that one day the Zetas obliged him to work for them, and they threatened him with death. But he realized that he was turning migrants in to be kidnapped, or for other businesses. He was a man with a conscience. He did not like that and started to feel really bad. One day something happened to him, and he knew that they were going to kill him. He said, "well if they are going to kill me, then let's take advantage and I am going to speak." And he spoke and 
asked to talk with a government agent and I talked with the government agent, and I heard all of his testimony, I recorded it. He told the government agent, "look, one time they threatened the Father to death. The Zetas? Yes..." And he discovered that time. He says that when Reinosa was about to kill me, that day he spoke to his boss on the phone. His boss is called or was called Adrián, in Piedras Negras. There are two Adriáns with the Zetas: the son, who was not in jail, and the other one, his father, who was in jail. And from jail, the father managed everything; he managed one hundred and fifty smugglers. And he spoke and he told him, "look, I am only calling you to confirm the execution of the priest." Juan Carlos, who they called the Chacal, was there, and when he heard, he knew what they were talking about because he was my friend, but he didn't say anything, he just stayed quiet, nothing more. He told Adrián, "do your job and for now leave the priest." That is why Reinosa came inside the refuge and didn't do anything, but I believe that they had some kind of ritual for when they say they will take care of a task, because he came into the refuge anyways. He had to, but he didn't kill me. That was the first time that I asked myself, "why didn't they kill me?" because Adrián had not met me. It is possible that Juan Carlos had talked with him and he had told him, "no, look, this priest does not get involved with us, he lets us do our thing," I don't know what he had told him.

Later on, they could have killed me twice, but they 
didn't kill me. I have asked myself many times, why if I was the one who persecuted the Zetas the most, the one who most impeded them, the one who filled criminal complaints against them. Why did they not kill me? I want to believe that maybe that time someone in that organization was like my protector. In 2013 when I came to the US with the caravan of migrants, in Tennessee, people from the Gulf of Mexico cartel approached me. There they could contact me when they wanted. And they told me, "look, I'm from the Gulf of Mexico cartel and my boss sent me to greet you and to tell you that, first, he respects you a lot because you have guts. And he respects valiant people, and he won't get involved with you. And I want to tell you that we are going to start charging the right to cross, that we are going to charge one thousand two hundred dollars for each migrant, from border to border. But we want to tell you that we are not going to do anything to you. Those who can't pay, they are going to return until they can pay." And I told him, "can you assure me that you are not going to do any harm to them?" "Yes-he told me-we are not going to do anything to them. But yes, we are not going to do anything for the reasons that I told you, but if you confront our narco-trafficking business, that's where you are a dead man." I told him, "that doesn't interest me. I am not the police. I am a pastor, I am interested in the migrants, not drugs, that is another thing." About one month and a half since that had 
happened, I went to Reinosa and I went to the blessing of a migrant shelter. We had a small press conference, and when the conference finished, two very strapping men dressed in red came up to me. And I thought they were journalists - my bodyguards were there, and I had about two or three years with them, and they were two or three meters from where I was and they didn't hear the conversation - and they told me, "look, we are the same ones who greeted you there in Tennessee, in the United States. Now you know who we are." And they told me, "we don't have any issue, we just came to present ourselves, to greet you, nothing more. There isn't any issue against you." I could not even say anything to my bodyguards.

We went to visit a cross outside, we walked to various places and we finally arrived at a restaurant, where the organizers of the House for Migrants had invited us. A small table. And one of them, of the religious ones - I told them what was happening - and she said, "let's see, allow me your tablet," to one of them who was there. And they start to see the photos and the whole time they were there behind me. In every moment. My bodyguards, didn't even notice. But those two people were behind me the whole time, the ones dressed in red. One of them was there, the commander had left to smoke outside of the restaurant, and he left me alone.

García-Caro: Are your bodyguards from the municipal police? 
Solalinde:

No, they are from the PGR (Attorney General of Mexico), and they are personal security agents from the PGR. That's how it was when I realized this, I said, "they didn't even notice, this commander, and just to go have a smoke, he left me alone." They could have killed me right then and there, and so I asked that they change the bodyguards and they did. But that happened. Since then, they never contacted me again.

García-Caro:

That scene that you are describing, the bodyguards go to smoke and the narcos stay really close by, that could be a scene from a contemporary Mexican movie. In which the state turns a blind eye. It seems like there are two states. I think that for me this is the most important question of contemporary Mexico. I have a colleague in CUNY, Oswaldo Zavala, who says that the narco does not exist, that the cartels do not exist. His book is entitled The Cartels do not exist, and he just presented it in Mexico. According to him, the cartels do not exist because this is actually a fiction that the state has assembled, and in reality they are all ramifications of the state, not even in decomposition, but of the state. I'm not so sure about that thesis and it seems a bit farfetched, I think the Mexican state does not have the organizational capacity for such control to occur. But rather there is a decomposition at all levels of the state, and almost a regionalization of feudal powers, we could say. What remains is a residual repressive state, in states like Oaxaca, with people like Ulises Ruiz before, and now 
maybe a state that returns with MORENA. If MORENA wins: what capacity is there to recover a state of judicial guarantees? They are many questions together. First let's address the decomposition or collapse of the state; and second, in what way can one return to a State of social and legal guarantees?

Solalinde:

I believe that it is very possible... the state of damage, the deterioration of the state is very great. Because there is practically no government institution that is not infiltrated by organized crime. It is also true that corruption is very great and that the state has been reduced in the face of capitalist factual power. However, all is not lost yet, still not everything is lost. And I believe that Mexico still has many resources to propel itself, to defend itself and to save itself. Andrés Manuel, I do think that he can channel the tiredness of the people, but also what he is going to do is of Pipila. He's going to try to dynamite the door, so that we can enter. Going in, he is not the one who has to say how things are going to be done because nobody wants him, nor he, to establish a presidential rule. He cannot, he does not want to be a continuation of the PRI chief executives. So what he is going to do is go in, so that the people can govern, but this sounds romantic if we do not talk about the how, of the organizations, of the times. He's going to come in, we are going to enter, and then we're going to have to start organizing.

What is the hope of rescue? First, recover internal 
sovereignty. I'm not talking about economic emancipation, that's another thing. That's a big subject. But right now for us, recover first the consciousness of what we are, the identity. Value our roots of the native indigenous peoples, recover that. Then, to believe that we can produce what is ours, that we can leave the consumerist capitalist sphere a little bit, and start consuming our own products, whatever we do have. Here there is a very interesting principle of liberation: the capitalist power over Mexico, is based exactly on economic dependence. But if we stop consuming things that we can consume in our market, the influence, the dependence, will decrease. We have tianguis, we have clothes, we have everything. But we can also produce things that we do need, cleaner, more organic, healthier, and that we can even, why not, think even of a barter economy. Not as a future, but as a strategy of survival and resistance, while looking for the way to impact the international market, in a less dependent manner. But the economists will say, "that's not it." But we are talking about a rescue of Mexico, yes.

We have a very rich cultural wealth; we still have spiritual wealth, as a way to reduce corruption. Andrés Manuel is only the pretext, so that in reality, all the capable people, because we are many, very capable people, that we can organize from below and build a new country. I do not know if you have had the chance to see the town of Cherán. Now, with the new organization it has, it is a prime example of liberation, of autonomy. The security is in the hands of the people. They are 
called rounds, because the people themselves take turns and manage the safety and security. And then there is a greater council that is the authority. That major council is named for the different camps. In the corners when they talk about what happens, they name it. I mean, there can be nothing more democratic than that. Diego: the role of women in Cherán. The women lost their fear there, they made men lose their fear and they administer themselves. Also, a very smart thing: they did not have to break with the government, with the institutions. No, they knew how to use them, how to use them for their purposes. That allows them to distance themselves from the parties; there are no political parties. So then they take care of their forests, they take care of their resources. I was just there when they celebrated the seventh anniversary of their autonomy.

García-Caro: ...they were influenced by the Zapatista movement...

Solalinde:

...A little, but it's very different. Look, they have taken distance, they are related, but they have taken distance from the Zapatista experience. The Zapatistas had to do it like they did because it was a war. They [Cherán] no longer had to wage an armed war; they had to make an intelligent, strategic war. While the Zapatistas do not want to know anything about the government, they do not receive anything from the government. Not here; here they said yes to the usages and customs, and everything that is of the government comes here, 
because it is ours, it belongs to the people, but it does not prevent our freedom. So they are using the government for the development and consolidation of that experience. They have seven years of a new and different education, where children and young people are coming to terms with what is happening, and you could see that on the day of the anniversary: fifty-eight schools marched and each school represents a different picture, where you can see the consciousness of the girls, of the boys. What an incredible thing! Mexico can achieve something similar, not as a recipe for cooking, but as a very deep inspiration of what we can do.

I believe that Mexico can move forward and be a more egalitarian country. If I believe that we are going to go taking down the oligarchy and not leave everything to them, because they are voracious, because they are addicted. A tycoon is an addict, a money addict. Man or woman, I do not care, they already live to have, and there is nothing more unbalanced, more crazy, more sickly than that. To think that the meaning of life, the goal of life, is to live to have things that you will never take with you, that are going to stay here. I have seen so many things here in the United States that I say, "poor men!" That $1 \%$, I'm not angry with the $1 \%$; I feel a lot of compassion for that $1 \%$, because they are the main victims closest to the capitalist nucleus. They are at the heart of capitalism and are the first to get screwed by capitalism; they do not live; they will not live. They are going to have. 
Can Mexico rescue itself? Yes, it's going to be rescued, but we need to advance, little by little, in order for people to have a minimum of confidence in themselves. Hope, we have it, but we need confidence. And that day - because we are going to win - that day we are already discussing in many ways, in the networks, how we are going to celebrate it. I have ideas, as Solalinde, I have ideas of how we are going to celebrate in anticipation. I have two gestures: first, I will create a group of women, "Women for Peace," and I will do it soon, and I will invite women from all parties, from all religions; to the wives of the candidates with the condition that they go only as women, and prepare them to understand that there they are women, their titles are left out, their husbands and political parties and beliefs and pedigrees, all are left out. There they are just going to come as women. And if possible, we are going to make a very beautiful gesture.

It is all a planning; it is going to be a symbolic planning of the women who are going to meet. It is a meeting of women to see them, regardless of the electoral ups and downs, what they will do for Mexico. Them, women, only the women, just women. Then we are going to meet in a symbolic place for them to speak. And from there generate a political advocacy group, as a moral authority. It is very important that they pull the other women and that they guide where they want to go with Mexico. Cherán is the example; it is an example that we live in Cherán. 
I'm going to summon young people, a group of "Youth for Peace." I am going to summon the young people to simply make a song. A chant, a song. Somewhere I do not know yet, symbolic, and we'll sing "Impossible Dream" ("Sueño Imposible"). Quixote's song. "Impossible Dream," because doing it and thinking that we are able to dream, that we can change the world. Dream. And then, the day we win, I plan to invite all the people, all the people as a gesture of liberation, but also to thank God, we'll take out bells. Everyone has bells in their houses, and they will take them out to the street and start ringing them. Small bells, big bells, whatever they are. Bells of freedom for Mexico, the independence of Mexico, as the beginning of a new Independence, now an economic one. But that takes time, we are not going to face macroeconomics right now, but we are going to concentrate on ourselves, consolidating our identity, our values, our resources and the dynamics of a better life. I think it is possible.

Contreras-Medrano: I have two questions about what you are saying right now, about security and about Andrés Manuel. First about AMLO, because it is more connected. What strategies can we follow, or what strategies should MORENA redefine to attract more votes? The votes that were for Marichuy, to attract that vote. What strategies should be followed to attract their votes to MORENA? 
Solalinde:

The only strategy that I have used with people, is to say, "Look, I am not from any party-and really, I am not from any party, I have never been or will be from any party-but I am a conscious person and I am an agent of change, and I'm interested in things changing. They can not continue as they are." All my influence, my prestige, I am putting it at the service of change and the only one that can change things, is Andrés Manuel. He will not make the total change; it will be like the transition. But it will start then to convince people. "If not, what option do you give me, Meade?" Can PRI lead the change? No. PAN then? PAN had 12 years to do it. Why would they do it now if they didn't do it before? He had the full opportunity and he did not do it. Why are you going to do it now?" Then say, "Does it sit well with you, do you sympathize with MORENA or not, or do you think that Andrés Manuel has many faults or many mistakes?" I tell them yes. But he is the only one who can get the PRI out of Los Pinos and he is the only one who can help us start the change. Either you take it or leave it, but if you are not with it, then once and for all you vote for Meade, go vote for the PAN, there is no other way. There is no other argument; there is no other way. The elections are now two months away and there is no candidate other than those you see; the others are more of the same, it is to prop up the capitalist system, to condemn Mexico to violence and inequality. So the only way is to put all our weight in the only hope of change. As one wise writer of La Jornada said, "I do not like Andrés Manuel. It is 
of interest to me to change. I'm going to vote for him, then after we win, l'll fight tooth and nail with him." So he put it in the financial section, and it made sense to me. Yes, there will be people who are not convinced by Andrés Manuel. Let's face it, we do not have the ideal leader; they do not exist, there is no ideal leader, but it is what we have. Take it or leave it. Either you take it in order to try to change, fight for change, or resign to continue living as you are living today. This is how easy the approach is, there is nothing else, there is no option.

Contreras-Medrano: The law of internal security, what do you think is behind it?

Solalinde:

Well, for what it seems, there is nothing behind it, everything is clear. It is already in place, like what happened in Honduras. Look, in Honduras first they passed a similar law on internal security; then Juan Orlando comes in and consolidates the shameless dictatorship, supported by the United States. And as you are protesting, the internal security law comes along and they are applying it with armed forces, with the police. They want to do the same with Mexico, but Mexico is not Honduras. Mexico is not Honduras, and be careful because if miscalculated, they can lose everything. Right now still, Andrés Manuel has been very clever by telling them, jokingly, but he told them: "Look, be smart and leave your position in the least problematic way possible." He told them, "do not even cough, do not 
make more problems." If the people do not want them, what are they going to disguise, a fraud? Be careful because even he will not be able to contain people. I myself say, I am for peace. But nobody can say that the people will not win, and in a latter case, I would not like it because with violence we lose all and everyone. But if they lead the people to another path for survival, violence is legitimate and then we will get to see how. Up until now, we are thinking about peaceful things, about processes that we are thinking, about processes of change. Strategic and peaceful. The oligarchy, through its spokesmen who are Videgaray and Peña and Meade and Nuño, are determined to crush the people and impose themselves, who knows...

Contreras-Medrano: Do you believe there is United States interventionism?

Solalinde:

Certainly yes. The United States will always want the unconditional, but at a given moment, if they see the loss, they are pragmatic. "I do not care if it's you or your godfather. I want you to turn in what is mine. Period." There is no problem, because besides Andrés Manuel as a start to these processes, he does not have the strength, he does not have the capacity to begin with directly confronting the capitalist factual powers. But he's going to start putting things forward that are going to seek greater equality, more development for the people. He has to start processes because if he tries to do something right now, not even the soil under his feet would support 
him at the time of the hour, because we are a fearful people, an ignorant people, that truthfully, has a lot of reading to do. But if you can start processes of awareness, of organizations; generate information structures towards people and participation and decision; from the people up. Now that could work, a scenario of very broad participation of consciousness; campaigns where we consolidate as Mexico, I think it is possible. Look, Evo Morales, he taught me a lot. In Bolivia, I saw many beautiful things; in Bolivia, for example, I did not see them hate the lousy rich! I did not see that there. There is a respect for all. There is an oligarchy, but people are all with Evo and with these processes. They are on their own, no one even pays attention to them, and now they can do whatever they want. The United States obviously still wants the wealth, the lithium and all the resources that Bolivia has. They want them, but they cannot do it because they are all united around Evo Morales, and Evo Morales has found the legal form of how to continue in the lead, because he knows that right now he is still needed.

So then yes, we can do it. We can recover the water, we can recover the oil, we can recover it. Of course we can.

García-Caro: Just like that it was lost, as the final ending of the Mexican Revolution. I remember that when I was [in Mexico] in 2013 to 2014, Peña Nieto's legislation was just being passed, to be able to privatize Pemex for the first 
time, to begin to privatize the oil industry. That is exactly the end of Revolutionary Cardenismo; it is the last nail that was missing from the coffin of the Revolution. This is one of the basic principles of sovereignty, which is that of communal property, mineral products and national reserves. That is the first thing that should be changed.

Solalinde:

Another thing that has to change - and they're not asking me - but it's going to be very exciting, it is the church: the hierarchy. The church has arrived late to all the events in the history of Mexico. In the Independence, it was on the side of the conquerors and the colonizers. It was on their side. In the Reformation, it was on the side of the conservatives, of the monarchy.

García-Caro: ...although it was a priest, like Solalinde, who started the Revolution...

Solalinde:

...in the Reformation, the church was against the liberals. In the Revolution too. In the Cristero War, there they left the hierarchy, the priests and the lay people. They were alone. The hierarchy had nothing, except at the end in the Arreglos: in the end, because the church is very obedient, they imposed the Arreglos. The Church returns to the same situation today: the people once again face the oligarchy, the tyranny - because Peña Nieto is a tyrannical government. So now is time to for us to unite. On which side will the Church be? If the Church - the hierarchy - makes the same mistake again 
and does not support the people, it will end up alone. And once again people will continue to marginalize it; again because the church is made up of the baptized, not the hierarchy or anything else. We are the ones who are making the revolution.

García-Caro:

But you have not answered yet about natural resources and sovereignty...

Solalinde:

The natural resources will be managed by the people once again. I am not opposed to the privatization of whatever may be privatized. But, taking everything away and passing into the hands of private property is risky. Because we are seeing that, in Bolivia, it is advantageous not to privatize the water, the strategic resources that serve for a greater development of the majority. And finally, what have we gained with the energy reform? What have we gained by giving profits to foreign companies? Nothing. The money from gasoline and oil goes to them. Who are keeping the profit? They take the profits, not us. Then we have to fight for resources. Mexico needs to be reorganized, and the economy too. I imagine that, instead of going shopping to large and big malls, going to the tianguis, for example: the tianguis are very good, there is not anything more beautiful than the tianguis. You find everything there: your clothes, your guayabera, things that we have. Even crafts! Everything, all the beautiful colors that we have. You have to go there, go to the tianguis. So many things 
that are ours, and you do not even have to fight with the transnationals. Just don't buy from them, and that's it.

No more consumerism. The government also has to reduce its expenses. There is a very nice word that Andrés Manuel uses a lot: austerity. Austerity does not mean starvation. Austerity is learning to build, to be a consumer of what is necessary, and that's it. And to live free. Even when there is a lot? How great that there is a lot! I compared it with a buffet. In a buffet you have many options, and if it is a good buffet, it will have entrees, desert, everything. But, are you going to eat everything because there's a lot? You are not a warehouse; you are going to take what you can, in the amount that your body can receive. And only that, otherwise you damage it. Is there a lot? Well, good. But to be free of that, to learn to be free of things and not depend on consumerism. We can do all that.

Contreras-Medrano: I have a question about the Church: it is not ethically correct to tell people who to vote for, but we know that the Catholic Church, the priests, have become political agents, as it is in your case. But we also have a lot of priests insisting on voting for the PAN, for the PRI. What can be done to raise the ethical awareness of the Fathers, of the Church?

Solalinde:

It's very difficult. Look, it's as if you sent me to Guerrero to talk with Calleja or the Viceroy or the Archbishop of that time, to talk them into the independence movement. 
Because these nowadays bishops, although they are good people, they are privileged. They live above people. They do not have the experience of hunger; they do not have the experience of being around ordinary people. It is very difficult; they are going to abstain. Look, if I showed you the notes that I sent to the episcopate spokesman, I tell him, "the situation is like this." He will not say anything to the Church, as a spokesman, he will not say anything. I push him to say something, but he does not say anything. Quiet. I believe that the Catholic hierarchy is not going to do much. But here is where the people, thank God, are already growing a little. People are already maturing; they are not going to be so childish as to ask permission from the bishop or the parish priest, to do what they have to do. Do you understand me? As a priest, I am also an example of this. I'm not going to ask permission from any bishop, any brother priest, to comply with Mexico. What I have to do, it's my responsibility, nobody can tell me anything. They do not want to do anything? It's their problem; I'm going to do it. Whatever it is. At any time.

Contreras-Medrano: In your opinion, what is the migration agenda that Andrés Manuel should follow?

Solalinde:

The first thing he has to do is to separate the political from the administrative in the aspect of security. It is the first thing he has to do, in fact, the law does account for this distinction, the immigration law of February 24 2011. 
It accounts for it, migration is an administrative matter and in fact, the character of the National Institute of Migration is administrative. Because it is not the police, because it has no weapons, because it does not have to perform Public Ministry work, or anything like that. But in practice it does, because the law is one thing, but the regulation, the secondary law that tells you how to apply the law. That's where they cheated, and also in the guidelines. Those two things. Therefore, they de facto considered migration as if it was more of a security body. That's my opinion, separating and leaving migration alone; the administrative aspect of migration. If I put these two things together, it turns into a source not only of violation of Human Rights, but also of corruption. Because that's where federal migration agents become corrupted. What I would do, would be to revitalize and implement and monitor the Programa Especial de Migración (Special Migration Program). The Programa Especial de Migración was put in place by a great man, Omar de la Torre, a great defender of Human Rights who was a government official at that time, and he did it with many civil society organizations for over two years. For two years we did it; when we finished it, Felipe Calderón did not manage to publish it and Peña Nieto published it in the Official Gazette. He published it as mandatory, and also included two bureaux to follow up: the Ministry of Public Administration and Governance. He makes it mandatory and has all the bureaux sign. When this guy realizes that it was a commitment with Human Rights, 
he puts it aside and forgets about it. Then I complained with him and said, "why? This is our work." He ignored me, he put it aside. Oh! but last year, in Switzerland, he boasted about it and presented it as an achievement of his government, when he, in fact, had ignored it. Then the Programa Especial de Migración must be updated, it must be monitored. And one more thing, all the recommendations must be respected, and also the UN reiterations regarding Mexico's public migration policy; Mexico must rethink that, and fulfill those commitments.

Another very important thing: we do not have to fight with the United States; we do not even have to fight with Trump. There are things we can do without asking for his permission. For example, if we really want migrants to stop migrating, the wall will not be useful, nor will the National Institute of Migration, because they become corrupt. They do business with this institution; they take the Americans for fools. A comprehensive development program must be done in Central America, Mexico and the United States. It is convenient for the United States to invest in this program, because this is the real solution. I personally discussed this in Central America with authorities from Central America and Mexico, the State Department, and Ambassador Antonio Wayne and he said, "we like this plan, we are willing to do it." There is a word they often say, "we are ready; I am ready; We are ready." The condition was that Mexico ought to be the leader, that there must be transparency in the process, and that everything should be done jointly. It 
was never undertaken because Mexico did not have the political will; there was no interest. But something must be done now with the co-responsibility of the sending countries in Central America, it has to be done. All this has to be reviewed: to gather all the shelters, to gather more than 90 civil society organizations that have to do with migrants, and among all of us, generate those transparent public policies that everyone knows. And tell the US, "it's going to be like this." And that's it. The resource that the United States gives through the Merida Initiative has nothing to do with Human Rights. Because, although they say that they set up the conditions for Human Rights, in practice nothing is done. We want it to be said and done.

Another thing. We want Europe to apply the clause regarding Human Rights to trade agreements between Europe and Mexico. We want them to apply it, because they have not done it. But the government itself can apply it. Right now, it would be AMLO, but what is going to happen after him? We want Human Rights not to be something circumstantial, but something structural and permanent. All that has to be done.

García-Caro:

There are models of plundering and exploiting migrants that are so spectacular, perhaps not yet visualized enough. For example, in the United States, detention and processing centers of migrants are privatized centers; they are concessions of the Federal State to private institutions, and they keep migrants for six months, and 
these institutions charge $\$ 75$ a day for each migrant, or something like that. With which, again, it would be a way to pay for the space used. Almost like what is happening in Mexico, but done in the American style. That is, with large centers, all very regulated, computerized and modern. Because for them it would be preferable if you Mexicans had made privatized detention centers, and that you had made a business. Instead of having done it informally, with narcos. That is the American model. Should you have carried out an American model...?

Contreras-Medrano: That is the real migration problem. The migration problem is that there is no clear separation between the security and administration work. The problem is not that people migrate; the problem is that we criminalize them, stop them. That's the problem.

Solalinde:

The new immigration policy has to discontinue the detention centers immediately. Detention centers must disappear immediately. No migration agent, no policeman, should chase any migrant. Undocumented migration has to be recognized as an administrative fault, because the law is very clear. It says there, that it is an administrative fault. And nobody is going to be put in jail or chased or beaten for an administrative fault. But detention centers do so, because it is a great contradiction, and that is what the UN committee says to Mexico, on September $13^{\text {th }}$ of last year, in response to the Third Universal Periodic Review. The UPR. Immigration 
detentions must be removed; if the migrants want to knock at the US doors, "you are welcome, come on in. Nobody is going to stop you." Of course! It's their problem; it's not our problem. It's the US problem. If they let them in, if they get in, it's their problem, but Mexico does not have to be a US immigration police anymore. That's embarrassing. I want to be honest. The US never told Mexico, "Violate their rights. Abuse them." They have placed six economic sanctions against Mexico, for abuse of authority, for violations of migrants' human rights. At least six economic sanctions. 